\title{
PENGARUH PEMBERIAN VITAMIN E TERHADAP GAMBARAN HISTOLOGIS TUBULUS PROKSIMAL GINJAL PADA MENCIT BETINA DEWASA (Mus musculus L) YANG MENDAPAT LATIHAN FISIK MAKSIMAL
}

\author{
The Effect Of A-Tocopherol Administration To The Histologist Cell Tubulus Proximal At \\ Female Adult Mouse (Mus Musculus L.) Which Made To Obtain Maximum Physical Exercise. \\ Nina Olivia \\ Dosen Tetap Yayasan Akper Kesdam I/BB Medan \\ email : nina_biomed@yahoo.co.id
}

\begin{abstract}
Abstrak
Penelitian ini bertujuan untuk mengetahui pengaruh pemberian Vitamin E terhadap gambaran histopatologi pada mencit betina dewasa (Mus musculus L.) yang mendapat latihan fisik maksimal. Penelitian ini memakai mencit betina dewasa (Mus musculus .L) sebanyak 25 ekor yang dibagi dalam 1 kelompok kontrol dan 4 kelompok perlakuan. Kelompok pertama (P0) sebagai kontrol yang tidak mendapat perlakuan apapun. Kelompok kedua (P1) mendapatkan latihan fisik maksimal setiap hari selama 30 hari, kelompok ketiga (P2) mendapatkan latihan fisik maksimal dan larutan aquadest $0,5 \mathrm{ml} /$ hari per oral selama 30 hari, kelompok keempat (P3) mendapatkan latihan fisik maksimal setiap hari selama 15 hari pertama, kemudian 15 hari berikutnya diberikan latihan fisik maksimal dan vitamin E 2mg/hari per oral setiap hari, kelompok kelima (P4) mendapatkan latihan fisik maksimal dan vitamin E 2mg/hari per oral setiap hari selama 30 hari. Hasil yang didapat menunjukkan pemberian Vitamin E tidak mempengaruhi bobot ginjal mencit betina dewasa (Mus musculus L.) yang mendapat perlakuan latihan fisik maksimal ( $\mathrm{P}>0,05)$, tetapi pemberian Vitamin E mempengaruhi rata-rata gambaran histologis tubulus proksimal ginjal mencit betina dewasa (Mus musculus L.) yang mendapat perlakuan latihan fisik maksimal $(\mathrm{P}<0,05)$. Latihan fisik maksimal menyebabkan terjadinya stres oksidatif yang mempengaruhi gambaran histologis tubulus proksimal ginjal, Vitamin E sebagai antioksidan dapat menekan jumlah luas kerusakan tubulus proksimal ginjal dengan dosis $2 \mathrm{mg} / \mathrm{hari}$ secara oral selama 15 hari.
\end{abstract}

Kata kunci : vitamin E,latihan fisik maksimal, histologis tubulus proksimal ginjal , NTA

\begin{abstract}
This research is intended to know the effect of $\alpha$ - tocopherol administration to the histologist cell tubulus proximal at female adult mouse (Mus musculus L.) which made to obtain maximum physical exercise. This research used 25 mice which divided into one control group and four treatment groups. The first group (P0) as the control group did not obtain any treatment. The second group (P1) obtained only maximum physical exercise everyday in 30 days, the third group (P2) obtained maximum physical exercise and $0,5 \mathrm{ml} /$ day per oral aquadest in 30 days, the fourth group (P3) obtained only maximum physical exercise everyday in the first 15 days, and obtained maximum physical exercise and $2 \mathrm{mg}$ /day per oral tocopherol in addition for the next 15 days, the last fifth group (P4) obtained maximum physical exercise and $2 \mathrm{mg} /$ day per oral tocopherol in 30 days. The result showed that tocopherol administration did not influence the average of weight renal mice (Mus musculus L.) which obtained maximum physical exercise $(\mathrm{P}>0,005)$, but the tocopherol administration influence the average the histologist cell tubulus proximal of female mature mice (Mus musculus L.) which obtained maximum physical exercise $(\mathrm{P}<0,005)$. Maximum physical exercise did not lead the occurrence of oxidative stress which affected the weight of renal, tocopherol as antioxidant could depress necrotic histologist cell tubulus proximal renal with 2 $\mathrm{mg} /$ day per oral dose in 15 days.
\end{abstract}

Key words: Tocopherol, Maximum Physical Exercise, Histologist Tubulus Proximal Renal, NTA 


\section{Pendahuluan}

Latihan fisik merupakan pergerakan tubuh yang dilakukan oleh otot dengan terencana dan berulang yang menyebabkan peningkatan pemakaian energi dengan tujuan untuk memperbaiki kebugaran fisik (Pedriatics, 1994, Laila,2007). Latihan fisik maksimal dapat memicu ketidakseimbangan antara produksi radikal bebas dan sistem pertahanan antioksidan tubuh yang di kenal dengan stres oksidatif (Leeuwenburgh, 2001). Latihan fisik maksimal dapat menyebabkan terjadinya stres oksidatif pada tikus (Senturk et al., 2001) dan manusia (Sonneborn and Barbee, 1998; Pedersen and Hoffman-Goetz; Senturk et al., 2005; Escobar et al., 2009). Selama latihan fisik maksimal, konsumsi oksigen seluruh tubuh meningkat 20 kali, sedangkan konsumsi oksigen pada serabut otot di perkirakan meningkat 100 kali lipat. Peningkatan konsumsi oksigen ini berakibat meningkatnya produksi radikal bebas yang dapat menyebabkan kerusakan sel (Ji, 1999). Radikal bebas merupakan molekul dimana elektron yang terletak pada lintasan paling luar tidak mempunyai pasangan (Gillendwater, 1991; Halliwell, 1995). ROS (Reactive Oxigen Species) adalah bagian dari radikal bebas yang merupakan produksi dari metabolisme sel normal. Sebahagian ROS berasal dari proses fisiologis (ROS endogen) dan lainnya adalah ROS eksogen, seperti berbagai polutan lingkungan (emisi kendaraan bermotor dan industri, asbes, asap rokok, dan lain-lain), radiasi ionisasi, infeksi bakteri, jamur dan virus, serta paparan zat kimia (termasuk obat) yang bersifat mengoksidasi. Berbagai jenis ROS adalah superoksida (O2), hidroksil (OH-), alkoksil (RO-), peroksil (ROO-) dan hidroperoksil (ROOH). Di dalam tubuh, radikal bebas yang paling banyak terbentuk adalah superokside. Superokside dapat dirubah menjadi hydrogen peroksida. Hidrogen peroksida kemudian diubah menjadi radikal hidroksil. Radikal hidroksil inilah yang dapat menyebabkan peroksidasi lipid pada membran sel sehingga terjadi kerusakan sel (Cuzzocrea, et al.,2001).

Ginjal adalah organ yang merupakan gabungan dari unit struktural bernama nefron. Nefron sendiri terdiri atas glomerolus dan tubulus yang berfungsi membuang bahan-bahan sampah dari hasil pencernaan atau metabolisme dan mengontrol volume dan komposisi cairan tubuh. Fungsi pengaturan ginjal ini memelihara kestabilan lingkungan sel-sel yang diperlukan untuk melakukan berbagai macam aktivitasnya. Jalannya fungsi ginjal tersebut dapat terganggu akibat kerusakan komponennya (Munawar, 2009). Salah satu penyebabnya adalah obstruksi pada ginjal. Radikal bebas terbentuk pada keadaan hipoksia sel, hal ini dapat terjadi pada tekanan intrarenal meningkat akibat obstruksi ginjal. Dan menyebabkan perubahan hemodinamik kemudian penurunan ATP (Adenosine triphosphate) yang merupakan sumber energi sel. Metabolisme anaerob menyebabkan perubahan biokimia sel yang berakibat kerusakan sel dan timbulnya radikal bebas yang merusak sel dan vaskular (Yusuf, 2000).

Latihan fisik dengan aktifitas maksimal akan menyebabkan otot berkontraksi secara anaerob (Bompa,1990,Fox,1993). Nangaku (2006) menunjukkan analisis statistik hubungan bermakna antara jumlah kapiler peritubuler sebagai indikator fungsi ginjal. Histologis pada model tikus membuktikan apotosis sel tubulus ginjal terjadi akibat keadaan hipoksia. Kerusakan ginjal dapat terjadi secara langsung pada sel atau akibat gangguan sirkulasi darah (iskemi). Gejala kliniknya meliputi hipertensi, anemia dan gagal ginjal kronik. Gambaran morfologiknya tampak papila nekrotik, berwarna coklat kekuningan disertai timbunan hasil metabolisme fenasetin atau pigmen mirip lipofusin, kemudian papila hancur dan lepas dalam pelvis ginjal. Mikroskopik tampak papila mengalami nekrosis koagulativa, disertai kalsifikasi distrofik (Alpers, 2007). Korteks mengalami atrofi, fibrosis intertisial, dan sebukan sel radang. Dinding pembuluh darah kecil dalam papila dan submukosa saluran kemih menunjukkan gambaran khas penebalan membran basal yang positif pada pulasan PAS (Wijaya, 2005). Podhorska (2006) menemukan kerusakan pada tubulus distal setelah latihan fisik akut yang ditandai dengan perubahan sel dan inti sel yang membengkak, nekrosis dan apoptosis tubuler dengan penonjolan mikrovili pada tubulus proksimal yang terlihat dalam korteks tubulus pada mencit dewasa yang mendapat latihan fisik berlebih yaitu treadmill sampai kelelahan selama enam jam dalam empat minggu.

Vitamin E merupakan antioksidan dan berfungsi penting dalam pemeliharaan integritas membrane sel utama tubuh (Allan, 2001). Vitamin E mengendalikan peroksida lemak dengan menyumbangkan hidrogen ke dalam reaksi yang mampu mengubah radikal peroksil (hasil peroksida lipid) menjadi radikal tokoferol yang kurang reaktif, sehingga tidak mampu merusak rantai asam lemak dan selanjutnya melindungi sel dari kerusakan (Winarsi, 2007; Hariatmi, 2004). Penelitian yang dilakukan terhadap tikus dengan pemberian beberapa anti oksidan seperti vitamin C, Vitamin E, allupurinol, katalase, superoxida dismutase (SOD) pada oklusi arteri renalis binatang atau isolated ginjal dapat mengurangi peroksidasi lipid korteks dan memperbaiki fungsi ginjal. Bahkan mengurangi resiko penolakan ginjal (graft rejection) pada transplantasi ginjal. Percobaan perbandingan pada binatang dengan pemberian antioksidan dengan yang tidak diberikan antioksidan pada kerusakan ginjal pada obstruksi akut selama 14 hari dengan cara tindakan nefrektomi menemukan adanya kerusakan ginjal 
(berupa- nekrosis, destruksi glomerulus dan tubulus) yakni hilangnya pembuluh darah glomerulus dan tubulus proksimal serta ditemukan adanya kerusakan mikrofili sepanjang lumen tubulus antara kelompok yang diberikan antioksidan dan yang tidak diberikan antioksidan secara bermakna berbeda atau kerusakan ginjal lebih ringan pada kelompok yang diberikan antioksidan dibandingkan yang tidak diberikan antioksidan.

\section{Bahan dan Metode}

Rancangan pada penelitian ini adalah eksperimen. Pada penelitian ini menggunakan mencit (Mus musculus) dari strain Webster dewasa fertil berumur \pm 3 bulan dengan berat badan 25-35 gram. Mencit tersebut ditempatkan dalam (ukuran $30 \times 20 \times 10 \mathrm{~cm}$ ) yang ditutup dengan kawat kasa. Dasar kandang dilapisi dengan sekam padi setebal 0,5-1 cm dan diganti setiap tiga hari. Cahaya ruangan dikontrol persis 12 jam terang (pukul 06.00 sampai dengan pukul 18.00) dan 12 jam gelap (pukul 18.00 sampai dengan pukul 06.00), sedangkan suhu dan kelembaban ruangan dibiarkan berada pada kisaran alamiah serta di beri makan dan minum secara ad libitum.

Perlakuan pemberian latihan fisik pada mencit dengan cara berenang sampai kelelahan (Laksmi, 2010; Jawi et al., 2008; Yu et al., 2006; Leeuwenburgh and Li, 1998). Mencit di renangkan di dalam wadah kaca (ukuran 100 × 50 × $80 \mathrm{~cm}$ ) yang diisi dengan air setinggi $60 \mathrm{~cm}$, tidak ada jalan keluar. Saat mencit menghentikan segala gerakannya, kecuali gerakan untuk bertahan hidup (mempertahankan kepala tetap berada di permukaan air), hal ini dianggap mencit sudah melakukan latihan fisik maksimal. Segera setelah itu, keluarkan mencit dari wadah, keringkan dengan handuk kering, dan kembalikan ke dalam kandang.

Vitamin E yang diberikan adalah $\alpha$-tokoferol asetat yang dilarutkan dalam larutan tween aquadest. Dosis vitamin E yang diberikan adalah $2 \mathrm{mg} /$ hari per oral dalam $0,5 \mathrm{ml}$ larutan (Verma et al., 2001)

Pemberian vitamin E diberikan kepada lima kelompok mencit yang telah dibagi yang terdiri dari :

a) Kelompok I (P0) = terdiri dari 5 ekor mencit betina dewasa yang tidak diberi perlakuan (kelompok kontrol).

b) Kelompok II (P1) = terdiri dari 5 ekor mencit betina dewasa yang diberi latihan fisik maksimal setiap hari selama 30 hari.

c) Kelompok III (P2) = terdiri dari 5 ekor mencit betina dewasa yang diberi latihan fisik maksimal dan larutan aquadest $0,5 \mathrm{ml} /$ hari per oral selama 30 hari.

d) Kelompok IV (P3) = terdiri dari 5 ekor mencit betina dewasa yang diberi latihan fisik maksimal setiap hari selama 15 hari pertama, kemudian 15 hari berikutnya diberikan latihan fisik maksimal dan vitamin E $2 \mathrm{mg} /$ hari per oral setiap hari.

e) Kelompok V (P4) = terdiri dari 5 ekor mencit betina dewasa yang diberi latihan fisik maksimal dan vitamin E $2 \mathrm{mg} /$ hari per oral setiap hari selama 30 hari.

Setelah 30 hari perlakuan, masing-masing hewan coba dikorbankan dengan cara dislokasi leher dan dibedah Selanjutnya dilakukan pengamatan terhadap semua isolasi ginjal (30 ekor mencit jantan dewasa) maka ginjal kiri dan kanan diletakkan pada kertas ukur dan ditimbang pada timbangan mikrogram, kemudian dicatat berat masing-masing ginjal. Kemudian dilakukan tahap fiksasi dimana organ ginjal yang telah di potongpotong kemudian di masukkan kedalam larutan fiksatif Bouin selama 2-10 jam.

Pembuatan sediaan histologis menurut Suntoro, S.H, (1983) dengan metode parafin adalah : pertama fiksasi yakni pencucian dengan alcohol $70 \%$, kedua, dehidrasi dilakukan secara bertahap, dengan alkohol $70 \%$ selama 10 menit, alkohol $80 \%, 90 \%$, 96\%, masing-masing selama 60 menit, kemudian dengan alkohol absolut selama 30 menit, ketiga penjernihan Dilakukan segera setelah proses dehidrasi dengan menggunakan toluol murni, keempat, infiltrasi paraffin dilakukan di dalam oven dengan suhu $56 \circ \mathrm{C}$. Organ ginjal di masukkan kedalam campuran toluol-parafin dengan perbandingan 1:1 selama 30 menit. Kemudian berturut dimasukkan kedalam: Parafin Murni I selama 60 menit, Parafin Murni II selama 60 menit, Parafin Murni III selama 60 menit, kelima penanaman Blok parafin ginjal yang telah mengeras di tempelkan pada holder kayu sampai melekat erat, keenam pengirisan kemudian dipasangkan pada mikrotom. Pengirisan dilakukan dengan ketebalan $6 \mu \mathrm{m}$, ketujuh penempelan Pada gelas benda siolesi dengan larutan albumin mayer dan ditetresi dengan aquadest. Kemudian beberapa pipa parafin diletakkan di permukaan aquadest pada gelas benda dan dibiarkan beberapa saat, kemudian gelas benda dipindahkan ke meja pemanas hingga kering, deparafinasi, kedelapan pewarnaan Pewarnaan dengan Hematoxylin Eosin (H-E) melalui tahapan

a. Preparat dideparafinasi dalam xylol sampai bebas parafin.

b. Dimasukkan dalam alkohol 96\%, $90 \%, 80 \%$, $70 \%, 50 \%, 30 \%$, aquadest.

c. Diamsukkan dalam larutan hematoxylin Erlich selama 1 menit.

d. Dicuci dengan air mengalir, dicelupkan kedalam aquadest, alkohol 30\%, 50\%, 70\%

e. Kemudian dimasukkan kedalam larutan EOSin $0,5 \%$ selama 1 menit

f. Kemudian dimasukkan ke dalam alkohol $70 \%$, $80 \%,(0 \%$ dan alkohol absolut.

g. Selanjutnya dimasukkan kedalam xylol. 
Kesembilan, penutupan preparat ditutup dengan gelas penutup setelah ditetesi dengan canada balsem terlebih dahulu, lalu diberi label.

Pemeriksaan Histopatologi dan Penilaian Perubahan Jaringan Ginjal ( Tubulus Proksimal) : Prosedur Kerja: Setiap mencit dibuat preparat ginjal (kiri dan kanan) dan tiap preparat dibaca (dibagi) dalam 4 lapangan pandang yaitu keempat sudut bagian preparat dengan pembesaran 400 kali dengan memakai mikroskop, serta batasan jumlahnya setiap bagian lapangan pandang adalah 25 sel, kemudian disesuaikan dengan tingkat/derajat kerusakan $0,1,2,3$ dan 4 selanjutnya dicari rata-ratanya di 4 lapangan pandang. Sasaran yang dibaca adalah perubahan struktur (gambaran) histologis tubulus kontortus proksimal ginjal mencit, karena sel epitel tubulus proksimal mencit merupakan tempat absorbsi dan mengkonsentrasikan racun (Rubin, 2009).

\section{Kriteria Normal bila tidak diketemukan :}

a. Degenerasi Hidrofilik (pembengkakan pada sitoplasma)

b. Nekrosis (kematian sel),yang ditandai dengan perubahan sebagai berikut :

- Karyopiknosis (inti kecil dan padat)

- Karyolisis (inti pucat dan larut)

- Karyoreksis (inti pecah menjadi beberapa gumpalan)

Tingkat kerusakan sel epitel pelapis tubulus proksimal :

$0=$ Sel dengan inti dan sitoplasma yang masih dalam batas normal

1 = Sesuai dengan kriteria (degenerasi hidrofilik)

$2=$ Ditemukan nekrotik tubulus proksimal, dengan luas $<25 \%$

$3=$ Ditemukan nekrotik tubulus proksimal, dengan luas $26-50 \%$

$4=$ Ditemukan nekrotik tubulus proksimal, dengan luas $>50 \%$

\section{Hasil dan Pembahasan}

a. Bobot Ginjal Mencit Betina Dewasa (Mus musculus L.)

Setelah dilakukan penilaian terhadap bobot ginjal mencit (Mus musculus L) betina dewasa setelah melakukan aktifitas fisik maksimal pada tiap kelompok didapatkan hasil seperti yang telihat pada berikut :

Tabel Rata-rata Bobot Ginjal

\begin{tabular}{l|l}
\hline Perlakuan & Bobot Ginjal $(\mathrm{g})$ \\
\hline P0 & $0,21 \pm 0,05$ \\
P1 & $0,19 \pm 0,02$ \\
P2 & $0,21 \pm 0,03$ \\
P3 & $0,22 \pm 0,01$ \\
P4 & $0,23 \pm 0,01$ \\
\hline
\end{tabular}

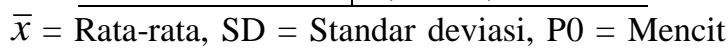
betina dewasa tidak diberi perlakuan (kelompok kontrol), P1 = Mencit betina dewasa yang diberi latihan fisik maksimal setiap hari selama 30 hari, P2 = Mencit betina dewasa yang diberi latihan fisik maksimal dan larutan aquadest $0,5 \mathrm{ml} /$ hari per oral selama 30 hari, P3 = Mencit betina dewasa yang diberi latihan fisik maksimal setiap hari selama 15 hari pertama, kemudian 15 hari berikutnya diberikan latihan fisik maksimal dan vitamin $\mathrm{E}$ $2 \mathrm{mg} /$ hari per oral setiap hari, $\mathrm{P} 4=$ Mencit betina dewasa yang diberi latihan fisik maksimal dan vitamin E $2 \mathrm{mg} /$ hari per oral setiap hari selama 30 hari.

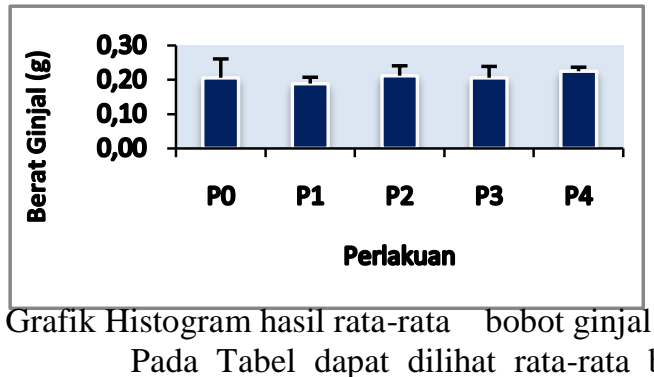

ginjal pada setiap perlakuan didapati paling tertinggi terdapat pada mencit betina dewasa yang diberi latihan fisik maksimal setiap hari selama 30 hari (P3) yakni $(0,23 \pm 0,01 \mathrm{~g})$, dan paling terendah pada mencit betina dewasa yang diberi latihan fisik setiap hari selama 15 hari pertama, kemudian 15 hari berikutnya diberikan latihan fisik maksimal dan vitamin E $2 \mathrm{mg} /$ hari per oral setiap hari (P1) yakni $(0,19 \pm 0,02 \mathrm{~g})$, namun kedua hasil tersebut bila masing-masing dibandingkan dengan kontrol didapati hasil yang perbedaan tidak nyata. Demikian pula diantara masing-masing perlakuan bila dibandingkan satu dengan perlakuan yang lain masih didapati perbedaan tidak nyata.

b. Penilaian Perubahan Jaringan Ginjal (Sel Ginjal Nekrotik) Mencit (Mus musculus L.) jantan

Hasil pengukuran dan perhitungan perubahan tubulus proksimal mencit (Mus musculus L) betina dewasa setelah melakukan aktifitas fisik maksimal ditampilkan.

Rata-rata Luas nekrotik Sel Ginjal tubulus Proksimal

\begin{tabular}{l|l}
\hline Perlakuan & $\begin{array}{l}\text { Luas Nekrotik Sel } \\
\text { Tubulus Proksimal }(\%)\end{array}$ \\
\hline P0 & $6,65 \pm 1,42^{\mathrm{a}}$ \\
P1 & $54,25 \pm 4,16^{\mathrm{a}}$ \\
P2 & $32,80 \pm 7,11^{\mathrm{b}}$ \\
P3 & $27,81 \pm 2,86^{\mathrm{b}}$ \\
P4 & $29,06 \pm 6,04^{\mathrm{b}}$ \\
\hline
\end{tabular}

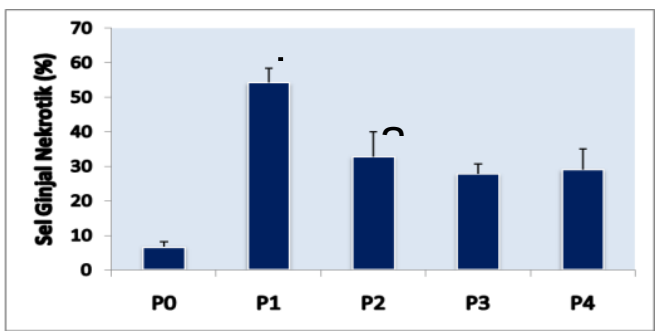


Gambar 2. Grafik Histogram hasil rata-rata perubahan jaringan Ginjal sel nekrotik.

Pada Tabel 4 dan Gambar 2 dapat dilihat rata-rata luas sel ginjal (tubulus proksimal) nekrotik yang terluas didapatkan pada P1 $(54,25 \pm 4,16 \%)$, jumlah sel ginjal (tubulus proksimal) nekrotik mencit betina dewasa pada setiap perlakuan didapati paling luas terdapat pada mencit betina dewasa yang diberi latihan fisik maksimal setiap hari selama 30 hari bila dibandingkan dengan kontrol, P2, P3 dan P4, didapati hasilnya berbeda nyata.

Rata-rata jumlah sel ginjal (tubulus proksimal) nekrotik mencit betina dewasa pada setiap perlakuan didapati paling sedikit luas kerusakan terdapat pada mencit betina dewasa yang diberi latihan fisik maksimal setiap hari selama 15 hari pertama, kemudian 15 hari berikutnya diberikan latihan fisik maksimal dan vitamin $\mathrm{E}$ $2 \mathrm{mg} /$ hari per oral setiap hari (P3) yakni $(27,81 \pm 2,86 \%)$, bila dibandingkan dengan kontrol, P2 dan P4 didapati hasilnya berbeda tidak nyata, namun bila dibandingkan dengan P1 didapati hasilnya berbeda nyata.

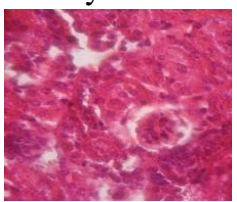

(a)

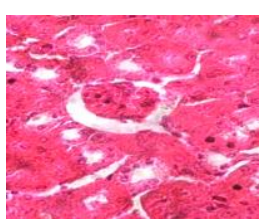

(c)

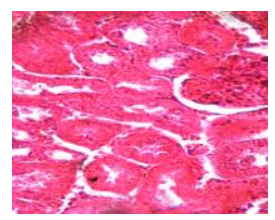

(e)

Gambar. Perubahan Struktur Histopatologi Jaringan Tubulus Proksimal Ginjal Mencit (a) P 0 (b) $\mathrm{P} 1$ (c) $\mathrm{P} 2$ (c) $\mathrm{P} 3$ (d) $\mathrm{P} 4$ (e) P 5. Melalui pembesaran $400 \mathrm{x}$

\section{Pembahasan}

\section{a. Bobot Ginjal (g) Mencit Betina Dewasa (Mus musculus L.)}

Pada penelitian ini didapati rata-rata bobot ginjal terberat pada mencit betina dewasa yang mendapat latihan fisik maksimal setiap hari selama 30 hari tidak nyata. Hal ini sesuai dengan hasil penelitian yang telah dilakukan sebelumnya oleh Wresdiyati dan Makita (2005) mendapatkan hasil adanya kondisi stres mengakibatkan terjadinya kelainan morfologi dan peningkatan jumlah organel peroksisomes pada ginjal kera. Wresdiyati, Made, dan I Ketut (2003), kerusakan sel disini termasuk kerusakan sel parenkhim ginjal dan kerusakan sel endotel pembuluh darah yang dapat mengakibatkan permeabilitas pembuluh darah meningkat, serta diapedesis sel radang atau leukosit. Proses fagositosis yang dilakukan oleh sel-sel inflamasi juga dapat menghasilkan radikal bebas. Kondisi ini lebih memperparah keadaan kerusakan sel akibat radikal bebas, termasuk terjadinya inflamasi. Menurut Ames and Shigenaga (1992), kondisi stres oksidatif dapat diinduksi oleh berbagai faktor seperti kurangnya antioksidan dan kelebihan produksi radikal bebas. Keadaan ini dapat mempengaruhi prosesproses fisologis maupun biokimia tubuh, yang mengakibatkan terjadinya gangguan metabolisme fungsi sel dan dapat berakhir pada kematian sel. Oksigen reaktif dapat bereaksi dengan beberapa makromolekul seperti DNA, protein, dan lemak. Gangguan dan kerusakan tersebut dapat menginduksi terjadinya berbagai penyakit dan proses degeneratif seperti penuaan dan karsinogenesis. Menurut Nayanatara (2004). Latihan fisik maksimal renang pada tikus dengan durasi 45 menit dengan suhu lingkungan $20^{\circ} \mathrm{C}$ selama tujuh hari memberikan gambaran makroskopis berupa peningkatan berat hati, ginjal, kelenjar adrenal dan kortek serebri.

Pada penelitian ini pemberian vitamin E 2 $\mathrm{mg} /$ hari per oral setiap hari setelah aktifitas fisik maksimal 15 hari berikutnya didapati rata-rata bobot ginjal yang terkecil, tetapi masih dalam batas normal. Hal ini menurut penelitian Suhartono et al., (2007) bahwa, vitamin E berada di dalam lapisan fosfolipid membran sel dan berfungsi melindungi asam lemak jenuh ganda dan komponen membran sel lain dari oksidasi radikal bebas dengan memutuskan rantai peroksidase lipid dengan cara menyumbangkan satu atom hidrogen dari gugus $\mathrm{OH}$ pada cincinnya ke radikal bebas, sehingga terbentuk radikal vitamin $\mathrm{E}$ yang stabil dan tidak merusak. Vitamin E berfungsi sebagai pelindung terhadap peroksidasi lipid di dalam membran.

\section{b. Penilaian perubahan jaringan ginjal (sel ginjal nekrotik) mencit (Mus musculus L.) jantan dewasa.}

Pada penelitian ini didapati penilaian perubahan jaringan ginjal (Tubulus proksimal) nekrotik mencit betina dewasa yang diberi latihan fisik maksimal setiap hari selama 30 hari nyata. Kemungkinan hal ini timbul karena adanya adanya stres oksidatif yang ditimbulkan oleh latihan fisik maksimal yang diberikan, sehingga meningkatkan akumulasi oksidan pengaruh radikal bebas yang menyebabkan kerusakan sel. Pengaruh radikal bebas yang menyebabkan kerusakan sel otot tungkai mencit yang ditandai oleh adanya 
semiquinone, diikuti dengan berbagai kerusakan seluler karena peroksidasi lipid seperti hilangnya kelenturan retikulum sarkoplasma sel. Seperti pernyataan Astuti (1999), bahwa radikal bebas yang muncul pada tikus dapat terdeteksi pada otot tungkai dan hati tikus. Ini ditantandai dengan adanya semiquinone, diiringi dengan berbagai kerusakan seluler akibat peroksidasi lipid seperti hilangnya kelenturan sarkoplasma dan uncoupling mitokondria. Peningkatan kadar anion superoksida dalam sel menyebabkan akumulasi produk antara seperti peroksidasi lipid yang dapat mengubah integritas membran, bahkan dapat menyebabkan kematian sel.

Pada penelitian ini didapat jumlah perubahan jaringan ginjal (Tubulus proksimal) nekrotik mencit betina dewasa yang diberi latihan fisik maksimal setiap hari selama 15 hari pertama, kemudian 15 hari berikutnya diberikan latihan fisik maksimal dan vitamin E $2 \mathrm{mg}$ /hari per oral setiap hari terdapat perbedaan tidak nyata.

\section{Simpulan Dan Saran Simpulan}

Berdasarkan hasil dan pembahasan diatas, dapat disimpulkan sebagai berikut :

1. Pemberian vitamin E tidak mempengaruhi bobot ginjal mencit betina dewasa (Mus musculus L) yang mendapat perlakuan latihan fisik maksimal

2. Pemberian vitamin $\mathrm{E}$ mempengaruhi nyata $(\mathrm{p}<0,05)$ gambaran histologis tubulus proksimal mencit betina dewasa (Mus musculus L) yang mendapat perlakuan latihan fisik maksimal

\section{Saran}

a. Disarankan adanya penelitian lanjutan dengan memeriksa berbagai indikator stres oksidatif.

b. Membandingkan vitamin $\mathrm{E}$ dengan antioksidan lain seperti vitamin $\mathrm{C}$ dan beta karotin dalam menekan oksidan (radikal bebas) yang diakibatkan oleh latihan fisik maksimal pada mencit betina.

\section{Daftar Pustaka}

Allan, S.,2001. Michael, IL, Timothy DN. Neural Control of Force Output During Maximal and Submaximal Exercise. Sports Medicine 31(9). p. $637-50$.

Belviranh M, Gokbel H. Acute exercise induced oxidative stress and antioxidative stress and antioxidant changes., 2006. Eur J Gen, 126131.

Bompa T.O. Theory and Methodology of Training. Toronto, Ontorio, Canada, Kendall/Hunt Publishing Company., 1990. p. 343.

Brezis M, Rosen S. Hypoxia of the renal medulla: its implication for disease., 1995 N.Eng J Med, 332: 647-55.

Coller BS. Leukocytosis and ischemic vascular disease morbidity and mortality: is it time to intervene? Arterioscler Thromb Vasc Biol., 2005 Apr;25(4):658-70.

Cooper, K.H. 1994. Antioxidant Revolution, Thomas Nelson Publishers, NashvilleAtlanta-London-Vancouver.

Eckardt K, Bernhardt WM, Weidemann A, Wernecke C, Rosenberger C, Wiesener WS, Willam C., 2005. Role of hypoxia in the pathogenesis of renal disease. Kidney Int , 68:S46-S51.

Fox SI. Muscle., 2003. Mechanism of Contraction and Neural Control. In : Fox SI. Human Physiology, 8nd ed. McGraw-Hill, p. 343.

Gillenwater JY., 1992. The pathophysiology of urinary tract obstruction. In: Campbell's urology. Sixth Ed. W.B. Saunders. Philadelphia, London, Toronto, Montrel, Sydney,Tokyo. Vol I: 499-532.

Gunduz F, Senturk U.K, Kuru O, Aktekin B, M.R. Aktekin. 2004. The effect of One Ywer's Swimming Exercise on Oxidant Stress ans Antioxidant Capacity in Aged Rats, (4) 3: 121-176.

Guyton AC, Hall JE. 2006. Textbook of medical physiology. Eleventh ed. Philadelphia: Elsevier saunders;

Halliwell B, Gutteridge JMC. 1994. Free radicals, antioxidants, and human disease. Curiosity, cause, or cosequence?. Neurogenerative disease research Group, King College, London . Vol. 344. 721-725.

Hariyatmi. 2004. Kemampuan vitamin E sebagai antioksidan terhadap radikal bebas pada lanjut usia. MIPA, 14(1), 52-60

Jawi, I.M., Suprapta, D.N., Subawa, A.A.N. 2008. Ubi Jalar Ungu menurunkan Kadar MDA dalam Darah dan Hati Mencit setelah Aktivitas Fisik Maksimal. Jurnal Veteriner, 9(2), 65-72.

Ji.L.L. 1999. Antioxidant Enzyme Response to Exercise and Aging. Med Scient Sport Exercise, 25, 225-231.

Junqueira, L.C., Carneiro, J., Kelley, R.O., ahli bahasa, Jan Tambayong. 1995, Histologi Dasar. Edisi ke 8, Jakarta. EGC.:370-387.

Junqueira, L.E., Carneiro, J., Kelley, R.O. 2005, Basic Histology. 11 ${ }^{\text {th }}$ Edition, Boston: Mc Graw-Hill, p: 373-90.

Khassaf M, McArdle A, Esanu C, Vasilaki A, McArdle F, Griffiths RD, et al. Effect of vitamin $\mathrm{C}$ supplements on antioxidant defence and stress proteins in human lymphocytes and skeletal muscle. J Physiol. 2003 Jun 1;549(Pt 2):645-52.

Laksmi, D.N.D.I. 2010. Glutathion meningkatkan kualitas tubulus seminiferus pada mencit yang menerima pelatihan fisik berlebih. Buletin Veteriner Udayana, 3, 719-21

Leeuwenburgh, C., Ji, L.L. 1998. Glutathione and Glutathione Ethyl Ester Supplementation of 
Mice Alter Glutathione Homeostasis during Exercise. The Journal of Nutrition, 128, 242026.

Leeuwenburgh C, Heinecke J.W.2001. Oxidative stress and Antioxidants in Exercise. Current Medicinal Cemistry Rev. 8(7):829-838

Munawar. 2009. Uji Toksisitas Akut Ekstrak Valerian (valerian Officinalis) terhadap Ginjal mencit Balb/C. J Farmakologi UNDIP

Nangaku. 2006. M. Chronic hypoxia and tubulointerstitial injury: a final common pathway to end-stage renal failure. J Am Soc Nephrol ,17:17-25.

Physical Fitness and Activity in School. 1994. American Academy of Pedriatics. Pedriatics , $93: 686-8$.

Poodhorska Marzena O, et.all. 2006. Expression of metallothionein in renal tubules of rats exposed to acute and endurance exercise. $\mathbf{J}$ Histology and embriologi,195-200-44

Poortmans JR, Vanderstraeten. 1994. J. Kidney function during exercise in healthy and diseased humans. An update. Sports Med 18: 419-437.

Sastrawan I.G.P. 2008. Peran Hipoksia Pada Patogenesis Penyakit Ginjal. J Penyakit Dalam. (1): 9(1).

Senturk UK, Gunduz F, Kuru O, Aktekin MR, Kipmen D, Yalcin O, et al. . 2001. Exerciseinduced oxidative stress affects erythrocytes in sedentary rats but not exercise-trained rats. J Appl Physiol. Nov; 91(5):1999-2004.

Senturk UK, Gunduz F, Kuru O, Kocer G, Ozkaya YG, Yesilkaya A, et al. 2005.Exerciseinduced oxidative stress leads hemolysis in sedentary but not trained humans. J Appl Physiol. Oct, 99(4):1434-41.

Suhartono E, Fachir H \& Setiawan B. 2007. Kapita Sketsa Biokimia Stres Oksidatif Dasar dan Penyakit. Universitas Lambung Mangkurat, Banjarmasin: Pustaka Banua.

Terblance SE. 2000. The Effects of exhausative exercise on the activity levels of catalase in various tissue of male and female. Cell Biol , 23(11):749-53.

Underwood JCE. 2000. Patologi Umum dan Sistemik. Vol.2. 2nd ed. Jakarta: EGC

Verma, R.J., Nair, A. 2001. Ameliorative effect of vitamin $\mathrm{E}$ on aflatoxin-induced lipid peroxidation in the testis of mice. Asian $J$ Androl, 3, 217-21

Wijaya A. 1996. Radikal bebas dan parameter status antioksidan. Forum diagnosticum. Prodia diagnostics educational services. No. 1. $1-11$.

Winarsi, H. 2007. Antioksidan Alami dan Radikal Bebas: Potensi dan Aplikasinya dalam Kesehatan. KANISIUS, Yogyakarta

Yusuf M.A, Widodo J.P, Soebadi D.M. 2000. Hubungan Radikal bebas dan Antioksidan dengan Kerusakan Ginjal Pada Obstruksi Akut, Eksperimen Pada Hewan Coba. Jurnal Bedah. 